\title{
Antioxidant activity of novel selena-diazole derivative against oxidative stress induced by dipyrone in female rats
}

\author{
Nadheerah F. Neamah ${ }^{1 *}$ iD, Abdul-Razzak Naaeem Khudair ${ }^{2}$, Shaker.A.N.Al-Jadaan ${ }^{3}$ \\ 1. Pharmacology \& Toxicology Department, College of Pharmacy, University of Basrah, Iraq \\ 2. Physiological Department, College of Veterinary, University of Basrah, Iraq \\ 3. Pharmaceutical Chemistry Department, College of Pharmacy, University of Basrah, Iraq
}

\begin{abstract}
Introduction: Selena-diazole has antioxidant, and antitumor activities. Also selena-diazol exhibited promising antifungal, antibacterial, viral infection and neurodegenerative disease. The aim of the study is to evaluate the antioxidant activity of a novel 4,4 -(4,5,6,7-tetrahydro- [1,2,3-] selenadiazolo [4,5 e] pyridine4,6-diyl) bis(benzene-1,3-diol) ( $\mathrm{T}$ ) against dipyrone (Di) induced oxidative stress.

Methods: In vitro antioxidant using DPPH, concentrations of $\mathrm{T}$ and ascorbic acid (AA) at 10, 20, 30, 40 and 50 $\mathrm{gg}$ was measured. In vivo study conducted using four groups, received $50 \mathrm{mg} / \mathrm{kg}$ of $\mathrm{T}$ or/and $\mathrm{Di}$ and $\mathrm{DW}$ for 30 days. Antioxidant estimated in vivo by serum superoxide dismutase activity (SOD); Glutathione Peroxidase enzyme GPx measured by using Rat SOD1 kit and Rat GPX1 ELISA Kit respectively. Furthermore, Malondialdehyde (MDA) is reliable biomarkers to predict oxidative stress.
\end{abstract}

Results: The results indicate $\mathrm{IC}_{50}$ rate using $\mathrm{DPPH}$ of $\mathrm{T}$ compound $48.888 \mu \mathrm{g} / \mathrm{ml}$. GPx of T and T\&Di groups were significantly increased. SOD of T was significantly increased than other groups. MDA results presented essential reduction in T group value than Di group.

Conclusion: The study concluded that synthesized novel selena-diazole derivative $T$ has a good effect as an anti-oxidant.

http://dx.doi.org/10.32598/ppj.24.3.60

\section{Keywords:}

Antioxidant;

Selena-diazole;

DPPH:

MDA;

GPx;

SOD

\section{* Corresponding author:}

N.F. Neamah

Email:

nadheerah.neamah@uobasrah.edu.iq Tel: (+647) 801471701

Received 6 May 2019; Received in revised form 25 March 2020; Accepted 30 March 2020

\section{Introduction}

Selena-diazole has antioxidant, and antitumor activities. Also selena-diazol exhibited promising antifungal, antibacterial, viral infection and neurodegenerative disease. In general, selenium containing compounds restores antioxidant enzyme activity like glutathione peroxidase (GPx). Selenium is an oligo nutritional constituent with important biological roles. It acts as a prosthetic group in thioredoxin reductase enzyme and glutathione 
2<smiles>O=Cc1ccc(O)cc1O</smiles>

2,4-dihydroxybenzaldehyde<smiles>CC(C)=O</smiles>

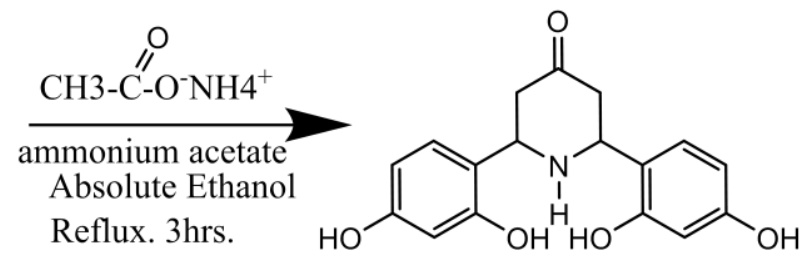

2,6-bis(2,4-dihydroxyphenyl)piperidin-4-one

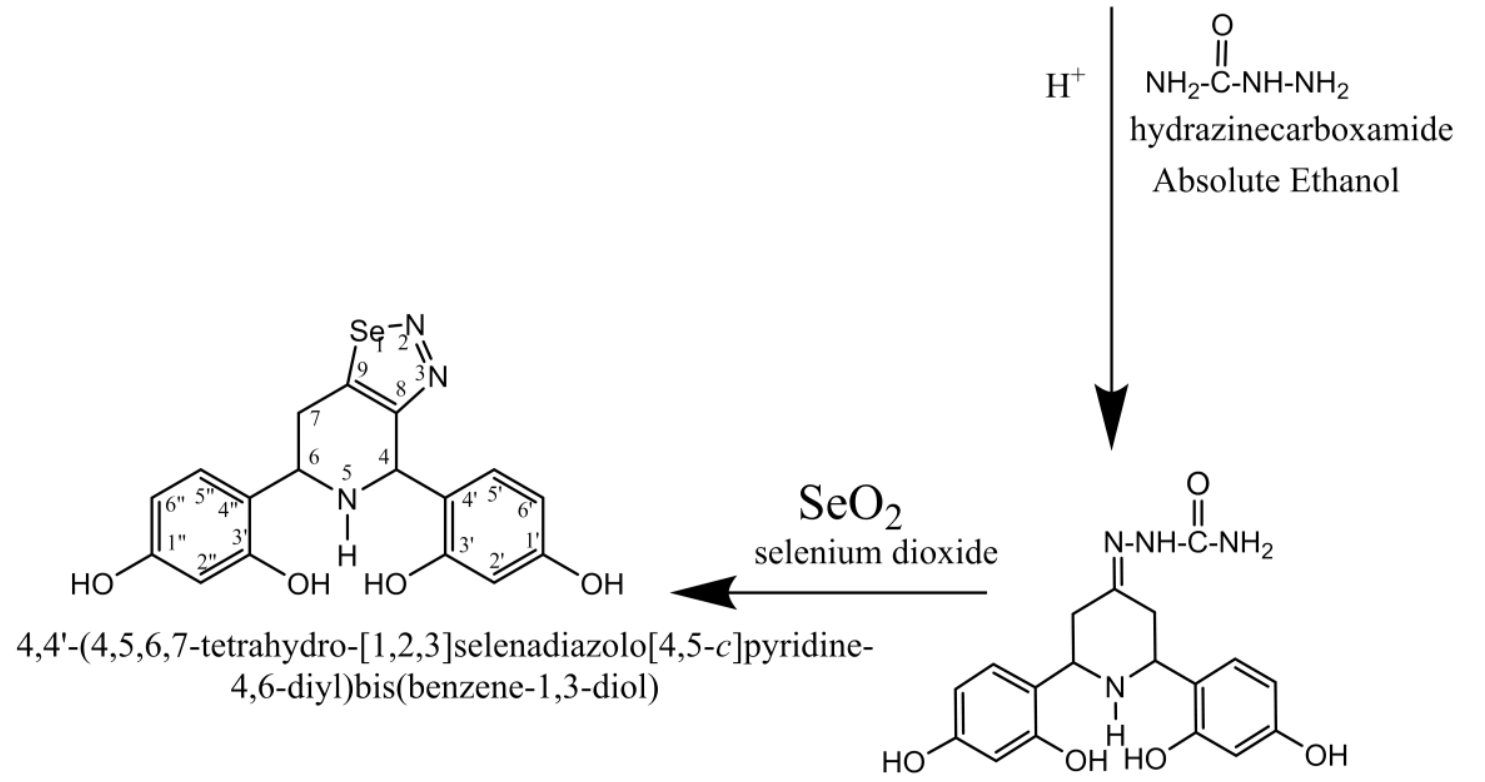

2-(2,6-bis(2,4-dihydroxyphenyl)piperidin-4-ylidene)hydrazine-1-carboxamide

Fig.1. Schematic illustration of the synthesis path way for preparation of novel selena-diazole derivative (Neamah et al., 2020)

peroxidase enzyme thus selenium considered as an effective free radicles scavenger (Ghorbel et al., 2017). Also, selenium has ability to oxidize thiol groups in both non- protein and protein as a consequence superoxide particle thus it can act as pro-oxidant. Selenium insufficiency is detected in numerous metabolic diseases, such as hyperlipidemia, hyper-glycemia and hyperphenylalaninemia. Addition of selenium may recover hyper-cholesterolemia, type1 diabetes mellitus, atherosclerosis and phenylketonuria. Furthermore, selenium has detoxification activity to heavy metal intoxication, when selenium added to diet and its deficiency related with several diseases such as chronic degenerative disease (Ansar et al., 2017). Imbalance in homeostasis in pro-oxidant results in creation of highly reactive oxygen species (ROS)/reactive nitrogen species (RNS) which can be an essential mediator of destruction to cell components such as DNA and lipids. Oxidative impairment acts as a vital role in health. ROS/RNS creation in low to moderate concentration induce molecular signals that mange a series of physiological actions specially regulates ventilation, preserves vascular tone and maintain rodex homeostasis supporting (Kurutas, 2016). Malondialdehyde (MDA) is a naturally occurring product of lipid peroxidation. Lipid peroxidation is a well-established mechanism of cellular injury and assists as a reliable biomarker of oxidation; therefore MDA is mutagenic and carcinogenic.

Organic selenium has larger bioavailability, with lower toxicity in comparison with inorganic compound. Firstly unstable compounds were synthesized like selenols. Various studies concentrated on development of more stables and easily purified organo-selenium compounds. Novel compounds have potential therapeutic effects towards several diseases, for example: cancer, microbial infections and neurodegenerative diseases. Selena diazole 
compound (T) compound was previously synthesized, characterized and identified. FT-IR spectra, melting point and TLC were measured in the department of Pharmaceutical Chemistry, College of Pharmacy/ University of Basrah/ Iraq. 1H-NMR and 13C-NMR spectra of ( $T$ ) compound was recorded using Bruker Ultra shield spectrophotometer (300 $\mathrm{MHz}$ ), University of Al-al-Bayt, Jordan. Median lethal dose and antimicrobial activity also measured (Neamah et al., 2020). The pathway of the synthesis illustrated in Figure 1.

Dipyrone (Di) or metamizole is a contentious drug, due to the hazard of its agranulocytosis side effect; therefore it's excluded for human use. The complete hazard of agranulocytosis related with the administration of pyrazolone drugs at an ordinary dose for short periods of time has been believed to be low. Nevertheless dipyrone still accessible in some countries in Europe like Spain and Germany (Costa et al., 2006). Thus antioxidant enzyme like catalase (CAT), superoxide dismutase (SOD) and GPx are used as indexes to calculate the level of oxidative stress ( $\mathrm{Li}$ et al., 2015). The current study aim to evaluate the antioxidant activity of a Novel $4, \overline{4}$ -(4,5,6,7-tetrahydro- [1,2,3-] selenad iazolo [4,5 e] pyridine-4,6-diyl) bis(benzene-1,3-diol) synthesized by authors against dipyrone induced stress.

\section{Materials and methods}

\section{Animal preparation}

Forty female rats obtained from College of Veterinary Medicine/Basrah University. All procedures of this study were approved by Veterinary Medicine College/ University of Basrah (Approved No:7/18/2420 At Nov $2^{\text {nd }}$ 2019), the animals kept in cages from polypropylene lined with sawdust (3-4rats/cage) and separated as groups. Rats were providing usual pellet diet and tap water. First, they were adapted to laboratory circumstance, natural day and night (12h day and $12 \mathrm{~h}$ night). Room temperature was $21 \pm 4^{\circ} \mathrm{C}$ (Kumar et al., 2017). Body weight of all rats was measured. Each animal group consist 10 female rats, the rats were orally received through oral gavage $50 \mathrm{mg} / \mathrm{kg}$ of body weight (BW) of $\mathrm{T}$ or/and $\mathrm{Di}$, dissolved in $2 \mathrm{ml}$ distilled water (DW) for 30 days. Control group received only $2 \mathrm{ml}$ of $\mathrm{DW}$. The rats after 30 days were sacrificed using chloroform anesthetic drug, the blood pull directly from the heart, blood sample kept in serum-separating tubes on room temperature for 20-30 minutes. Serum collected using centrifuges for $10 \mathrm{~min}$ at 4000 RPM.

\section{Antioxidant}

Radical scavenging assay using 2,2-diphenyl-1picrylhydrazyl (DPPH)

The antioxidant capacity of any synthesized or natural compound detected according to its scavenging capacity of the stable DPPH free radical. Mixing DPPH, $\mathrm{C}_{18} \mathrm{H}_{12} \mathrm{~N}_{5} \mathrm{O}_{6}(\mathrm{M}=394.33)$ solution with the test material that can offer a hydrogen atom, increases the reduced form with change of the violet color. If $\mathrm{DPPH}$ radical representing by $Z \cdot$, and the antioxidant or the donor molecule by $\mathrm{AH}$, reaction is $\mathrm{Z}^{\circ}+\mathrm{AH}=\mathrm{ZH}+\mathrm{A}^{\circ} \mathrm{o}$

The free radical $A \cdot$ obviously reacts with an additional $A \cdot$ molecule.
$A \cdot+A \cdot=A-A(2)$
(Alam et al., 2013)

DPPH conveys an intense absorption band at $517 \mathrm{~nm}$ and solution appears a deep violet color (Rached et al., 2018). In each examination all concentrations of the test substance were measured for antioxidant activity at the same time and then the examination was repeated to all concentrations for the second time using new preparation materials. Each concentration repeated 10 times.

\section{Preparation of DPPH}

DPPH solution was prepared by adding $7.89 \mathrm{mg}$ of $\mathrm{DPPH}$ to $100 \mathrm{ml}$ of DMSO, the resultant $0.2 \mathrm{mM} \mathrm{DPPH}$ solution was kept for $2 \mathrm{~h}$ in a dark by casing the test tubes and flask with aluminum foil, at room temperature $\left(23-25^{\circ} \mathrm{C}\right)$. The next step is adding $1 \mathrm{ml}$ of prepared DPPH to $3 \mathrm{ml}$ of DMSO, the absorbance was measured using $517 \mathrm{~nm}$, and recorded as control data (Mostafa et al., 2017).

\section{Preparation of tested sample (T) and ascorbic acid (AA) concentrations}

Five milligram of $T$ and $A A$ were weighted 3 times and then each dissolved in $10 \mathrm{ml}$ of DMSO. From this solution different concentrations of $T$ and $A A$ were prepared. First $1 \mathrm{mg}$ of each $\mathrm{T}$ and $\mathrm{AA}$ dissolved in $2 \mathrm{ml}$ of DMSO, each $\mathrm{ml}$ contain $500 \mu \mathrm{g}$ of $\mathrm{T}$ or $\mathrm{AA}$. Only $400 \mu \mathrm{l}(50 \mu \mathrm{g} / 100 \mu \mathrm{l})$ were added to $1600 \mu \mathrm{l}$ of DMSO, the resultant solution contain $200 \mu \mathrm{g} / 2 \mathrm{ml}$. T

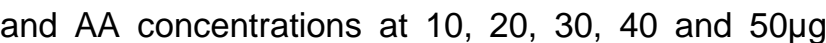
was prepared by sequent dilution as mention in Table 1 (Sherikar and Mahanthesh, 2015). 


\section{Measurement assay}

The spectrophotometric technique for measuring the antioxidant ability of $T$ and $A A$ are based on the reduction of the absorbance of the $D P P H$ radical. From each concentration of $\mathrm{T}$ and $\mathrm{AA}, 3 \mathrm{ml}$ was added into separated test tube. One $\mathrm{ml}$ of $0.2 \mathrm{mM}$ DPPH was added to each $T$ and $A A$ test tube. The mixture was shaking and stands for $10 \mathrm{~min}$ at room temperature. Then the absorbance measured via spectrophotometer at $517 \mathrm{~nm}$. AA first measured as reference standard material, inhibition of absorbance or DPPH scavenging activity was calculated by the equation:

Percent inhibition $=\left(A_{0}-A_{1} / A_{0}\right)^{*} 100$ (S.D.Sanja et al., 2009).

$A_{0}$ refer to the absorbance of control reaction and $A 1$ the absorbance in presence of $(T)$, or standard sample $A A$. The $I_{50}$ rate of the test sample was measured from concentration and inhibiting percentage curve. The $\mathrm{IC}_{50}$ of each diagnostic sample was measured according to the following formula:

$I_{50}$ for $T: y=13.161 x+14.635 ; I_{50}$ for $A A: y=$ $5.8935 x+54.502$

$Y$ are inhibition ratios, plotted against concentrations of the sample $X$, the regression line for each $(T)$ and AA $(\mathrm{Y}=\mathrm{a} \mathrm{X}+\mathrm{b})$ is drawn. Basically all point that measured is on the regression line and at least 2 points around $50 \%$ do not have deviation from the line (Shimamura et al., 2014). The $I_{50}$ is the concentration of an antioxidant at which 50\% inhibition of free radical activity is observed. The lower $I_{50}$ value indicates the greater overall effectiveness of the antioxidant. The $I_{50}$ of the compound was measured by spectrophotometric method (Hangun-Balkir and McKenney, 2012).

\section{Serum MDA levels assay}

Determination of MDA in different samples such as plasma, serum or tissue homogenates is one of the reliable biomarker to predict the oxidative stress levels (Singh et al., 2014). In the present study MDA measurement is carried out as reported by Yagi method (Yagi, 1998). The reaction achieved in acidic situations and at $95^{\circ} \mathrm{C}$. The resultant substance was TBARS "thiobarbituric acid reactive substances". TBARS can be measured by either fluorimetry (excitation at $532 \mathrm{~nm}$ and emission at $553 \mathrm{~nm}$ ) or colorimetry (532-535nm), (Atiba et al., 2016). The results estimated by the following equation:

$\operatorname{MDA}(\mu \mathrm{mol} / \mathrm{l})=(\mathrm{A} 1-\mathrm{A} 0 / 1.56){ }^{*} 10$

Where $A 1$ is test sample absorbance and $A 0$ is control absorbance (Antolovich et al., 2002).

\section{SOD activity}

The serum SOD is measured by Rat SOD1 kit (Superoxide Dismutase 1, Soluble) from Elabascience Biotechnology Inc. China. Detection rate $0.16-10 \mathrm{ng} / \mathrm{ml}$. Serum, plasma and other biological fluids can be used as a sample for SOD measurement.

\section{Measurements of $G P_{X}$}

Serum GPx enzyme $(\mathrm{pg} / \mathrm{ml})$ measured by Rat GPX1 (Glutathione Peroxidase 1) ELISA Kit, Elabascience Biotechnology Inc. China. Serum, plasma and other biological fluids can be used for GPx measurement.

\section{Results}

\section{DPPH radical scavenging assay (antioxidant} action)

The results of significant antiradical activity were showed in Table 2. Both of tested samples ( $T$ and $A A)$, in different concentration were evaluated for antioxidant effects. High scavenging effects observed up to $(80.027 \mu \mathrm{g} / \mathrm{ml} \pm 7.30)$ for ( $\mathrm{T})$ compound and $(82.74 \mu \mathrm{g} / \mathrm{ml} \pm 4.19)$ for standard antiradical AA. At low dose $10 \mu \mathrm{g} / \mathrm{ml}$ there were significant differences between (T) $28.4362 \pm 7.28132$ and AA $57.1962 \mu \mathrm{g} / \mathrm{ml}$ \pm 10.18565 . The antioxidant effects increased with increased concentration. The regression line for each ( $T$ ) and $A A(Y=a X+b)$, and $\mathrm{IC}_{50}$ was calculated. Median antiradical inhibition rate $\mathrm{IC}_{50}$ of $\mathrm{AA}$ is 40.75 and 48.88 of $\mathrm{T}$ compound (Fig 2).

\section{Serum SOD activity}

Serum SOD concentrations numerically elevated in all treated groups. When compared with DW group, the mean SOD of $\mathrm{T}$ group $(60.01 \mathrm{pg} / \mathrm{ml} \pm 9.08)$, was significantly greater than in DW group level (37.15pg/ml \pm 2.18$)$ and T\&Di group. While in Di and T\&Di groups, SOD values were $(39.97 \pm 3.28)$ and $(43.58 \pm 1.99)$ respectively, the concentration increments were statistically non-significant. The results are shown in Table3.

\section{Serum MDA levels assay}

Serum MDA of rats that received $\mathrm{Di}$ quantity was 


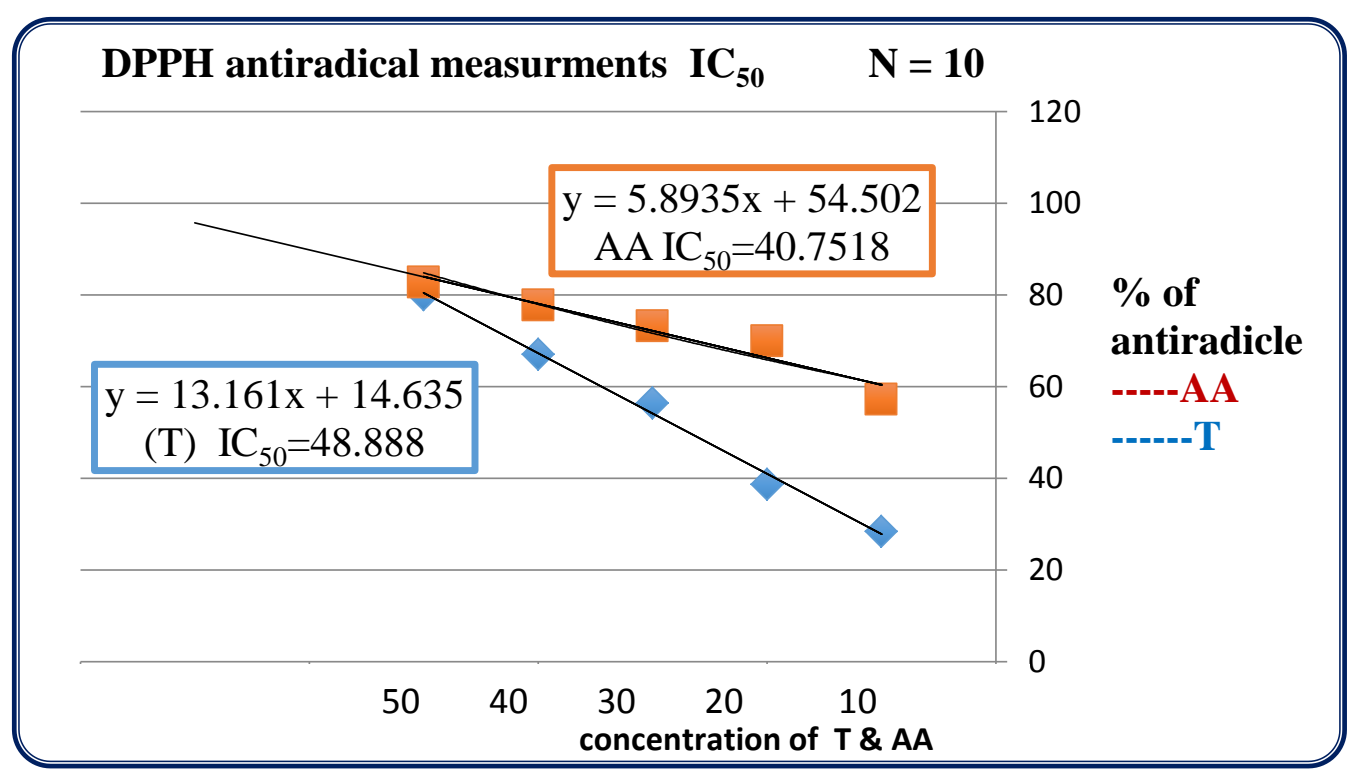

Fig.2. From the histogram median concentration inhibition $\left(\mathrm{IC}_{50}\right)$ calculated for both test selenadiazole derivative $(\mathrm{T})$ and ascorbic acid (AA). $\mathrm{N}=$ times of examinations of each $\mathrm{AA}$ and each of $\mathrm{T}$ concentrations. The differences between $\mathrm{T}$ groups, $P \leq 0.05$ vs. $A A$ at concentrations of $10,20,30$ and $40 \mu \mathrm{g} / \mathrm{ml}$.

Table 1: preparations of different concentrations of Test selenadiazole derivative $(T)$ and ascorbic acid (AA)

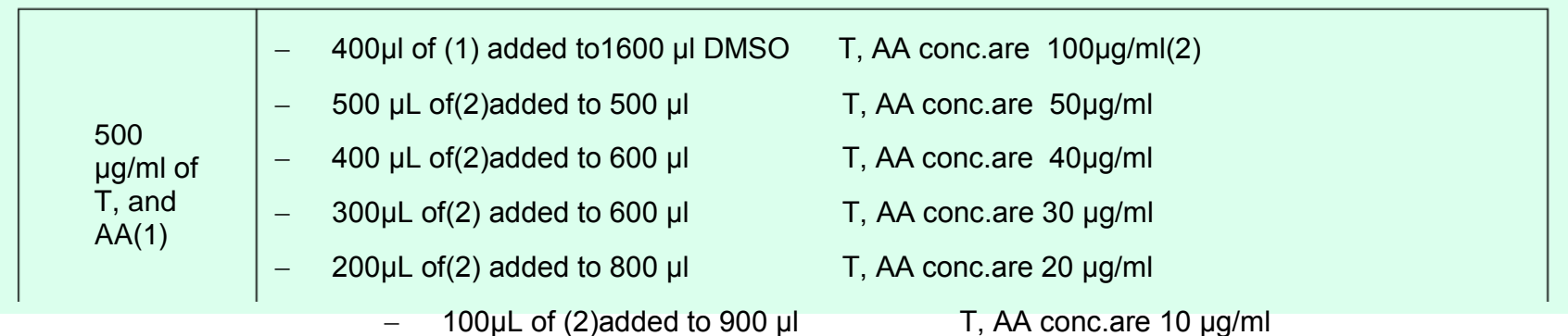

Table 2: Antiradical effects of $(\mathrm{T})$ compound enhanced with increase its concentration compare with standard antiradical $A A$.

\begin{tabular}{cccccc}
\hline \multirow{2}{*}{ Treatment groups } & \multicolumn{4}{c}{ Mean of Concentrations $(\mu \mathrm{g} / \mathrm{ml}) \pm$ SEM } \\
\cline { 2 - 6 } & $10 \mu \mathrm{g} / \mathrm{ml}$ & $20 \mu \mathrm{g} / \mathrm{ml}$ & $30 \mu \mathrm{g} / \mathrm{ml}$ & $40 \mu \mathrm{g} / \mathrm{ml}$ & $50 \mu \mathrm{g} / \mathrm{ml}$ \\
\hline (T) & $28.43 \pm$ & $38.63 \pm$ & $56.44 \pm$ & $67.05 \pm$ & $80.03 \pm$ \\
Compound & $7.8^{\circ}$ & $14.63^{*}$ & $6.4^{*}$ & $7.8^{*}$ & 7.31 \\
Ascorbic & $57.20 \pm$ & $69.94 \pm$ & $73.26 \pm$ & $77.77 \pm$ & $82.75 \pm$ \\
acid (AA) & 10.19 & 10.16 & 8.50 & 5.0 & 4.20 \\
\hline
\end{tabular}

*Significant differences at $(P<0.05)$. Results are expressed as mean $\pm \mathrm{SEM}$ of the mean of the ten replicates.

statistically non-significant elevated to (3.35 $\mu \mathrm{mol} / \pm 1.87)$ than in DW group MDA (1.96 $\mu \mathrm{mol} / \pm 1.5$ ). Also in rats received T\&Di group, the concentration reduced to $1.69 \mu \mathrm{mol} / \mathrm{I} \pm 0.41$, but not statically significant. Only $\mathrm{T}$ group $(0.61 \mu \mathrm{mol} / \mathrm{I} \pm 0.40)$ showed significant reduction than $\mathrm{Di}$ group, the results are shown in Table 3.

\section{GPx levels}

Administration of $\mathrm{T}, \mathrm{Di}$ and T\&Di compounds to female rats for 30days, then serum GPx was measured, after rats were sacrificed. It can be seen from the data in Table 3 that the results indicate significant enhancement in serum GPx concentration $\mathrm{T}$ group $(4532.67 \mathrm{pg} / \mathrm{ml} \pm 444.94)$ and T\&Di (3599.67 \pm 1058.63$)$ GPx level compare to DW group 
Table 3: illustrate the antioxidant activity of the experimental groups.

\begin{tabular}{|c|c|c|c|}
\hline \multirow{2}{*}{ Groups } & \multicolumn{3}{|c|}{ Parameters (mean \pm SEM) } \\
\hline & $\begin{array}{l}\text { GPx }(\mathrm{pg} / \mathrm{ml}) \\
\mathbf{N}=10\end{array}$ & $\begin{array}{l}\text { SOD }(\mathrm{ng} / \mathrm{ml}) \\
\mathrm{N}=10\end{array}$ & $\begin{array}{l}\text { MDA }(\mu \mathrm{mol} / \mathrm{l}) \\
\mathrm{N}=10\end{array}$ \\
\hline Distilled water & $1761.47 \pm 1055.02 \mathrm{~A}$ & $37.15 \pm 2.18 \mathrm{~A}$ & $1.96 \pm 1.57 \mathrm{~A}$ \\
\hline Dipyrone & $1526.01 \pm 627.18 \quad A$ & $39.97 \pm 3.28 \mathrm{~A}$ & $3.35 \pm 1.87 \mathrm{~A}$ \\
\hline Test & $4532.66 \pm 444.94 \quad B$ & $60.01 \pm 9.08 \mathrm{~B}$ & $0.61 \pm 0.40 \mathrm{AB}$ \\
\hline Test and Dipyrone & $3599.66 \pm 1058.63 \mathrm{~B}$ & $43.58 \pm 1.99 \mathrm{AC}$ & $1.69 \pm 0.41 \mathrm{~A}$ \\
\hline $\begin{array}{l}\text { LSD (Lesser Significant } \\
\text { Differences) }\end{array}$ & 1838.19 & 16.43 & 2.74 \\
\hline
\end{tabular}

Means bearing different capital letters vertically differs significantly at 0.05 level $(P<0.050)$. $\mathrm{N}$ refers to number of rats.

GPx level (1761.47pg/ml \pm 1055.024$)$. Di group GPx level was non-significantly reduced to

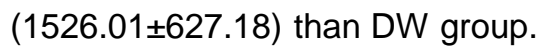

\section{Discussion}

Numerous studies have been revealed that ROS generated the epithelial cells damage, to reduce or prevent cellular damage. There are two endogenously antioxidant systems; the first system is preventive the antioxidant system and the second is cleaning antioxidant enzyme system, e.g. vitamin E, $\mathrm{C}$ and GPx that eliminate produced ROS, so plasma membrane lipid. GPx (selenium-dependent glutathione peroxidase) is one of the chief antioxidative enzyme in the cells and it has been shown that $\mathrm{Se}$ is a structural component of GPx (Hasanvand et al., 2017).

Antioxidant activity is not determined based on a single test model. Several in vitro and in vivo test techniques carried out for assessing antioxidant activities of the studied samples. Another characteristic is that models of antioxidant test differ in different respects. Consequently, it is difficult to compare completely between any methods with the others (Alam et al., 2013). As, it is difficult to compare among different methods, therefore the present study attempts to involve a wide diversity of antiradical procedures including in vitro DPPH scavenging test and in vivo $\mathrm{GP}_{\mathrm{X}}, \mathrm{SOD}$ and MDA tests.

\section{DPPH radical scavenging assay}

DPPH in vitro technique considered to be the simplest methods in comparison with other antioxidant in vitro technique characterized with fewer steps and reagents and practically low-cost, requires only a UV-V is spectrophotometer; therefore frequently used for in vitro antioxidant evaluation (Karadag et al., 2009).

The reduction ability of DPPH radical is measured by the decline in its absorbance at $517 \mathrm{~nm}$ induced by antioxidants. The reduction in its absorbance caused by antiradical, due to the progresses of antioxidant molecules and radicle reaction; results in the radicle scavenging by hydrogen donation (Shekhar and Anju, 2014). This study indicates that synthesized (T) has a DPPH radicals scavenging in "dose dependent manner" due to its antioxidant capacity, compared with ascorbic acid (S.D.Sanja et al., 2009). The present findings by (Ruberte et al., 2018), seem to be consistent with other research which found selenadiazole derivatives" twenty-seven novel benzo [c][1,2,5]selena-diazole-5-carboxylic acid (BSCA) derivatives" have potent in vitro radical scavenging activity using DPPH antioxidant method. This series of compounds can serve as an excellent scaffold to achieve novel and potent antioxidant complexes beneficial for several diseases. Several studies have confirmed that a lot of novels selena-diazole derivatives have DPPH radicle scavenging effects (Zhang et al., 2010).

\section{Glutathione peroxidase}

GPx and selenoproteins, which are generated by selenium consumption, have been involved to enhance the ability of antioxidant activity in the animal tissues and cells, which breakdown $\mathrm{H}_{2} \mathrm{O}_{2}$ to water. In mitochondria, GPx converts lipid peroxidation to conforming alcohols. GPx enzyme has a vital inhibitory role of lipid peroxidation and protects cells from oxidative stress (Ighodaro and 
Akinloye, 2019), also reduced ROS and RNS and protects lipids of DNA and protein. Furthermore, antiinflammatory properties of selenium have involved in cyclooxygenase and lipoxygenase sequences (Karavelioglu et al., 2015). GPx enzyme low activity is one of the early consequences of a disorder of the prooxidant/antioxidant equilibrium (Alam et al., 2013). In recent years, a number of studies focused on antioxidant effects of selenium compounds. It was documented that a decrease in oxidation with higher activity of GPx by addition of selenium into the diets (Amirkolaie et al., 2014). Also, the antiradical activity of selenoneine was measured, the results that reported similar to those obtained by authors in the present study (Yamashita et al., 2010). The result of present study is also supported by a study which revealed that important elevation in both GPx actions after administration of many organic-selenium compounds (Stefanello et al., 2015). Many authors recently found comparable results of antioxidant action of selenium (Ansar et al., 2017); (Hasanvand et al., 2017). The Di anti-oxidant effects in the current study was consistent with other study showed that $\mathrm{Di}$ decreases endogenous glutathione levels and inhibits GPx action in dose dependent manner (Sa'nchez et al., 2002); however, the results were contradicted by the experiments of peroxyl Radical ROO, that dipyrone has antioxidant activity (Costa et al., 2006).

\section{Superoxide dismutase}

SOD is the initial detoxification enzyme and more potent antioxidant enzyme that acts as a primary defense system in the cell. It activates the transformation of 2 molecules of superoxide anion (O-2) first to $\mathrm{H}_{2} \mathrm{O}_{2}$ and then molecular oxygen $\left(\mathrm{O}_{2}\right)$, changing the possibly destructive superoxide anion less (Ighodaro and Akinloye, 2019).

The results show that SOD of $T$ group exert significant elevation with SOD level of DW group, as well as with T\&Di group. These results might be due to hepato- protective special properties were evaluated by the capability to prevent lipid peroxidation, protein oxidation and to modify in the SOD (Schaffer et al., 2016). The results of current research support the idea that selenium containing compounds are more potent SOD inducer. Data from several sources have identified the increased SOD activity. The GPX and SOD plasma levels increased significantly in Se-supplemented-diet to diabetic rats for one month (Ghaffari et al., 2011). Another study demonstrates that diphenyl diselenide (PhSe) active in contradiction of increased oxidative stress in kidney and liver (Sartori et al., 2017). Pre-treatment with diphenylmethyl selenocyanate found to be the most powerful SOD and CAT inducer (Jayanta Kumar Dasa et al., 2013). Also, it was reported that 1, 4Anhydro-4-seleno-d-talitol (SeTal) has powerful antioxidant action in vitro and it's likely to stimulate wound healing in diabetic mice due to elevate SOD production and reduced $\mathrm{NO}$ formation ( $\mathrm{Ng}$ et al., 2017). Similar results revealed that Se effectively elevated significantly the activities of SOD, GPx and CAT compared to the Ag nano-particles treated group (Ansar et al., 2017).

\section{Serum MDA levels assay}

Once lipid peroxides are unstable compounds, they tend to degrade rapidly in a variety of sub products. MDA is one of the most known secondary products of lipid peroxidation and it can be used as a marker of cell membrane injury (Grotto et al., 2009). Enhance level of MDA is considered as an indicator of change of cell function and tissue damage. This event appears in the liver or kidneys due to ROS formation or free radicals. It is common that natural antiradicals can diminish intracellular oxidative stress by prevent free radicals generation (Rjeibi et al., 2017).

In the present study MDA concentrations of all testing groups are measured and the results indicate the only significant difference was between $\mathrm{T}$ and $\mathrm{Di}$ groups. The result of the present study agrees comparatively with a study of the effects of selenium on oxidative stress of cadmium in bone tissue in rats, the results reported decreased in MDA when Se added to rats previously exposed to cadmium compare to control group (Ibrahim et al., 2014). The results also supported a study showed that Se decreased high-sensitivity C-reactive protein in serum and elevated GSH level, resulting in reduction of plasma MDA (Wang et al., 2017) which reveals that the marker of lipid peroxidation MDA had a negative association with serum level of selenium in both normal, and hyper cholesterolemic (specifically negative associated with low-density lipoprotein) patients. Furthermore (Hasanvand et al., 2017) showed that administration of Se remarkably decreased MDA. Recent study (Amraoui et al., 2018) has reported that rats treated concomitantly with 
bisphenol A (BPA) and (Se + Vit E) displayed a significant decrease in MDA concentration as compared to BPA-treated group. Selenium could reduce the elevated MDA level by about 5 -fold compared to the diabetic rats (Ghaffari et al., 2011). A study by (Orhan and Sahin, 2001) observed that Di at the high concentration exerted an inhibition which is statistically significant on $\mathrm{H}_{2} \mathrm{O}_{2}^{-}$forced erythrocytic membrane lipid peroxidation. The results agree with our data and explain the elevation in MDA. In contrast, (Costa et al., 2006) concluded that none of pyrazolones that studied including $\mathrm{Di}$ was able of scavenging $\mathrm{O}_{2}^{-}$or $\mathrm{H}_{2} \mathrm{O}_{2}^{-}$. Pervious study by Batu and Erol (2007) found that elevated lipid peroxidation after Di administration, which confirms the results of current study. The study concluded that synthesized novel selena-diazole derivative $T$ has a good effect as an anti-oxidant.

\section{Conclusion}

which reveals that the marker of lipid peroxidation MDA had a negative association with serum level of selenium in both normal, and hyper cholesterolemic (specifically negative associated with low-density lipoprotein) patients.

\section{Acknowledgments}

To my dear friend Dr Manal Nasir and all staff of Pharmacology research Lab/College of Pharmacy for her help and support

\section{Conflict of interest}

The authors declare that there is no conflict of interest.

\section{References}

Alam MN, Bristi NJ, Rafiquzzaman M. Review on in vivo and in vitro methods evaluation of antioxidant activity. Saudi Pharm J 2013; 21: 143-152. https://doi.org/10. 1016/j.jsps.2012.05.002

Amirkolaie AK, Karimzadeh J, Kenari AA. The effects of organic selenium on performance and oxidative level in rainbow trout (oncorhynchus mykiss, walbaum, 1792) fed a high-fat diet. J Anim Feed Sci 2014; 23: 90-96. https://doi.org/10.22358/jafs/65721/2014

Amraoui W, Adjabi N, Bououza F, Boumendjel M, Taibi F, Boumendjel $A$, et al. Modulatory role of selenium and vitamin e, natural antioxidants, against bisphenol ainduced oxidative stress in wistar albinos rats. Toxicol Res 2018; 34: 231-239. https://doi.org/10.5487/tr.2018. 34.3.231
Ansar S, Alshehri SM, Abudawood M, Hamed SS, Ahamad T. Antioxidant and hepatoprotective role of selenium against silver nanoparticles. Int J Nanomedicine 2017; 12: 7789-7797. https://doi.org/10.2147/ijn.s168974

Antolovich M, Prenzler PD, Patsalides E, McDonald S, Robards K. Methods for testing antioxidant activity. Analyst, 2002; 127: 183-198. https://doi.org/10.1039/ b009171p

Atiba AS, Abbiyesuku FM, Oparinde DP, A T, Niran-Atiba, Akindele RA. Plasma malondialdehyde (mda): An indication of liver damage in women with pre-eclamsia. Ethiop J Health Sci 2016; 26: 479-485. https://doi.org/10.4314/ejhs.v26i5.10

Costa D, Marques AP, Reis RL, Lima JL, Fernandes E. Inhibition of human neutrophil oxidative burst by pyrazolone derivatives. Free Radic Biol Med 2006; 40: 632-40. https://doi.org/10.1016/j.freeradbiomed.2005.09 .017

Ghaffari T, Nouri M, Irannejad E, Rashidi aM-R. Effect of vitamin e and selenium supplement on paraoxonase-1 activity, oxidized low density lipoprotein and antioxidant defense in diabetic rats. Biolmpacts 2011; 1: 121-128. https://doi.org/10.5681/bi.2011.016

Ghorbel I, Elwej A, Chaabane M, Jamoussi K, Mnif $H$, Boudawara $T$, et al. Selenium alleviates oxidative stress and lung damage induced by aluminum chloride in adult rats: biochemical and histological approach. Biol Trace Elem Res 2017; 176: 181-191. https://doi.org/10.1007/ s12011-016-0818-9

Grotto D, Maria LS, Valentini J, Paniz C, Schmitt G, Garcia SC. Importance of the lipid peroxidation biomarkers and methodological aspects for malondialdehyde quantification. Quim Nova, 2009; 32: 169-174. https://doi.org/10.1590/S0100-40422009000100032

Hangun-Balkir Y, McKenney ML. Determination of antioxidant activities of berries and resveratrol. Green Chem Lett Rev 2012; 5: 147-153. https://doi.org/ 10.1080/17518253.2011.603756

Hasanvand A, Abbaszadeh A, Darabi S, Nazari A, Gholami M, Kharazmkia A. Evaluation of selenium on kidney function following ischemic injury in rats; protective effects and antioxidant activity. J Renal Inj Prev 2017; 6: 93-98. https://doi.org/10.15171/jrip.2017.18

Ibrahim TA, Tarboush HA, Aljada A, Mohanna MA. The effect of selenium and lycopene on oxidative stress in bone tissue in rats exposed to cadmium. Food Nutr Sci 2014; 05: 1420-1429. http://dx.doi.org/10.4236/fns. 2014.514155

Ighodaro OM, Akinloye OA. First line defence antioxidantssuperoxide dismutase (sod), catalase (cat) and glutathione peroxidase (gpx): Their fundamental role in the entire antioxidant defence grid. Alexandria $\mathrm{J} \mathrm{M}$ 2019; 54: 287-293. https://doi.org/10.1016/j.ajme.2017. 09.001

Jayanta Kumar Dasa, Sibani Sarkarb, Ugir Hossain Skc, Pramita Chakraborty, Das RK, Bhattacharya S. Diphenylmethyl selenocyanate attenuates malachite green induced oxidative injury through antioxidation \& inhibition of DNA damage in mice. Indian $\mathrm{J}$ Med Res 
2013; 137: 1163-1173.

Karadag A, Ozcelik B, Saner S. Review of methods to determine antioxidant capacities. Food Anal Methods 2009; 2: 41-60.

Karavelioglu E, Boyaci MG, Simsek N, Sonmez MA, Koc R, Karademir M, et al. Selenium protects cerebral cells by cisplatin induced neurotoxicity. Acta Cir Bras 2015; 30: 394-400. https://doi.org/10.1590/s0102-8650201500600 00004

Kumar TS, Rani S, K S, B P, P N. Toxicity evaluation of ammonium sulfate to albino rat. Asian J Pharm Clin Res 2017; 10. https://doi.org/10.22159/ajpcr.2017.v10i1. 15355

Kurutas EB. The importance of antioxidants which play the role in cellular response against oxidative/nitrosative stress: Current state. Kurutas Nutr J 2016; 15. https://doi.org/10.1186/s12937-016-0186-5

Li S, Tan H-Y, NingWang, Zhang Z-J, Lao L, ChiWoonWong, et al. The role of oxidative stress and antioxidants in liver diseases. Int $\mathrm{J}$ Mol Sci 2015; 16: 26087-26124. https://doi.org/10.3390/ijms161125942

Mostafa N, Eldahshan O, El-Beshbishy $\mathrm{H}$, Singab AN. Hepatoprotective, antihyperglycemic and cytotoxic activities ofjacaranda acutifolia leaf extract. Med Aromat Plants 2017; 13: 8. https://doi.org/10.4172/2167-0412. 1000297

Neamah NF, Khudair A-RN, Al-Jadaan SAN. Synthesis, characterization, antimicrobial activity and acute toxicity test of a novel $4, \overline{4}-(4,5,6,7$-tetrahydro- [1, 2, 3 -] selenad iazolo [4, 5 e] pyridine-4, 6-diyl) bis(benzene-1, 3-diol). Egyptian J Chem 2020; 63: 669-681. https://dx.doi.org/10.21608/ejchem.2019.11702.1753

$\mathrm{Ng} \mathrm{HH}$, Leo $\mathrm{CH}$, O'Sullivan K, Alexander SA, Davies MJ, Schiesser $\mathrm{CH}$, et al. 1,4-anhydro-4-seleno-d-talitol (setal) protects endothelial function in the mouse aorta by scavenging superoxide radicals under conditions of acute oxidative stress. Biochem Pharmacol 2017; 128: 34-45. https://doi.org/10.1016/j.bcp.2016.12.019

Orhan $H$, Sahin G. In vitro effects of nsaids and paracetamol on oxidative stress-related parameters of human erythrocytes. Exp Toxicol Pathol 2001; 53: 13340. https://doi.org/10.1078/0940-2993-00179

Rached W, Zeghada FZ, Bennaceur M, Barros L, Calhelha $\mathrm{RC}$, Heleno $\mathrm{S}$, et al. Phytochemical analysis and assessment of antioxidant, antimicrobial, antiinflammatory and cytotoxic properties of tetraclinis articulata (vahl) masters leaves. Ind Crops Prod 2018; 112: 460-466. https://doi.org/10.1016/j.indcrop.2017.12. 037

Rjeibi I, Feriani A, Ben Saad A, Ncib S, Sdayria J, Saidi I, et al. Phytochemical characterization and bioactivity of lycium europaeum: A focus on antioxidant, antinociceptive, hepatoprotective and nephroprotective effects. Biomed Pharmacother 2017; 95: 1441-1450. https://doi.org/10.1016/j.biopha.2017.09.035

Ruberte AC, Plano D, Encío I, Aydillo C, Sharma AK, Sanmartín C. Novel selenadiazole derivatives as selective antitumor and radical scavenging agents. European J Med Chem 2018; 157: 14-27. https://doi. org/10.1016/j.ejmech.2018.07.063

S.D.Sanja, N.R.Sheth, N.K.Patel, Patel D, Patel B. Characterization and evaluation of antioxidant activity of portulaca oleracea. Int J Pharm Pharm Sci 2009; 1.

Sa'nchez S, Marti'N MJ, Ortiz P, Motilva V, Lastra Candel. Effects of dipyrone on inflammatory infiltration and oxidative metabolism in gastric mucosa comparison with acetaminophen and diclofenac. Digest Dis Sci 2002; 47: 1389-1398. https://doi.org/10.1023/a:1015395 103160

Sartori G, Jardim NS, Sari MH, Flores EF, Prigol M, Nogueira CW. Diphenyl diselenide reduces oxidative stress and toxicity caused by hsv-2 infection in mice. $J$ Cell Biochem 2017; 118: 1028-1037. https://doi.org/10. 1002/jcb.25667

Schaffer TK, Wohlenberg MF, Medeiros N, Martins JB, Agostini F, Funchal C, et al. Evaluation of antioxidant activity of grapevine leaves extracts (vitis labrusca) in liver of wistar rats. An Acad Bras Cienc 2016; 88: 18796. https://doi.org/10.1590/0001-3765201620140658

Shekhar TC, Anju G. Antioxidant activity by dpph radical scavenging method of ageratum conyzoides linn. Leaves. Am J Ethnomed 2014; 1: 244-149.

Sherikar A, Mahanthesh M. Evaluation of aqueous and methanolic extract of leaves of epipremnum aureum for radical scavenging activity by dpph method, total phenolic content, reducing capacity assay and frap assay. J Pharmacogn Phytochem 2015; 4: 36-40.

Shimamura T, Sumikura Y, Yamazaki T, Tada A, Kashiwagi $\mathrm{T}$, Ishikawa $\mathrm{H}$, et al. Applicability of the dpph assay for evaluating the antioxidant capacity of food additives inter-laboratory evaluation study. Anal Sci 2014; 30: 717-21. https://doi.org/10.2116/analsci.30.717

Singh Z, Karthigesu P, singh $P$, kaur $R$. Use of malondialdehyde as a biomarker for assessing oxidative stress in different disease pathologies: a review. Iranian J Publ Health 2014; 43: 7-16.

Stefanello ST, Gubert P, Puntel B, Mizdal CR, Campos MMAd, Salman SM, et al. Protective effects of novel organic selenium compounds against oxidative stress in the nematode caenorhabditis elegans. Toxicol Rep 2015; 2: 961-967. https://doi.org/10.1016/j.toxrep. 2015.06.010

Wang N, Tan H-Y, Li S, Xu Y, Guo W, Feng Y. Supplementation of micronutrient selenium in metabolic diseases: Its role as an antioxidant. Oxid Med Cell Longev 2017; 2017: 13. https://dx.doi.org/10.1155/2017/ 7478523

Yagi K. Serum malondialdehyde measurements. Free Rad Antiox Prot 1998; 108: 101-106.

Yamashita Y, Yabu T, Yamashita M. Discovery of the strong antioxidant selenoneine in tuna and selenium redox metabolism. World J Biol Chem 2010; 1: 144-50.

Zhang YB, Zheng WJ, Huang Z, Yang F, Liu J, Chen TF. [spectrometric investigation of the antioxidant activity of a novel synthetic selenadiazole derivative spo against dpph and abts free radicals]. Guang Pu Xue Yu Guang Pu Fen Xi 2010; 30: 1866-71. 